\title{
Characterisation of recombinant pyranose oxidase from the cultivated mycorrhizal basidiomycete Lyophyllum shimeji (hon-shimeji)
}

\author{
Clara Salaheddin ${ }^{1,2}$, Yoshimitsu Takakura ${ }^{3}$, Masako Tsunashima ${ }^{3}$, Barbara Stranzinger ${ }^{1}$, Oliver Spadiut ${ }^{1}$, \\ Montarop Yamabhai ${ }^{4}$, Clemens K Peterbauer ${ }^{1}$, Dietmar Haltrich ${ }^{1 *}$
}

\begin{abstract}
Background: The flavin-dependent enzyme pyranose 2-oxidase (P2Ox) has gained increased attention during the last years because of a number of attractive applications for this enzyme. P2Ox is a unique biocatalyst with high potential for biotransformations of carbohydrates and in synthetic carbohydrate chemistry. Recently, it was shown that P2Ox is useful as bioelement in biofuel cells, replacing glucose oxidase (GOx), which traditionally is used in these applications. P2Ox offers several advantages over GOx for this application, e.g., its much broader substrate specificity. Because of this renewed interest in P2Ox, knowledge on novel pyranose oxidases isolated from organisms other than white-rot fungi, which represent the traditional source of this enzyme, is of importance, as these novel enzymes might differ in their biochemical and physical properties.

Results: We isolated and over-expressed the p2ox gene encoding P2Ox from the ectomycorrhizal fungus Lyophyllum shimeji. The p2ox CDNA was inserted into the bacterial expression vector pET21a(+) and successfully expressed in E. coli Rosetta 2. We obtained active, flavinylated recombinant P2Ox in yields of approximately $130 \mathrm{mg}$ per $\mathrm{L}$ of medium. The enzyme was purified by a two-step procedure based on anion exchange chromatography and preparative native PAGE, yielding an apparently homogenous enzyme preparation with a specific activity of $1.92 \mathrm{U} / \mathrm{mg}$ (using glucose and air oxygen as the substrates). Recombinant P2Ox from L. shimeji was characterized in some detail with respect to its physical and catalytic properties, and compared to the wellcharacterised enzymes from Phanerochaete chrysosporium and Trametes multicolor.

Conclusion: L. shimeji P2Ox shows properties that are comparable to those of P2Ox from white-rot fungal origin, and is in general characterised by lower $\mathrm{K}_{\mathrm{m}}$ and $k_{\text {cat }}$ values both for electron donor (sugar) as well as electron acceptor (ferrocenium ion, 1,4-benzoquinone, 2,6-dichloroindophenol). While L. shimeji P2Ox is the least thermostable of these three enzymes (melting temperature $T_{\mathrm{m}}$ of $54.9^{\circ} \mathrm{C}$; half-life time of activity $\tau_{1 / 2}$ of 0.12 at $50^{\circ} \mathrm{C}$ and $\mathrm{pH} 6.5$ ), P. chrysosporium P2Ox showed remarkable thermostability with $T_{\mathrm{m}}$ of $75.4^{\circ} \mathrm{C}$ and $\tau_{1 / 2}$ of $96 \mathrm{~h}$ under identical conditions.
\end{abstract}

\section{Background}

Pyranose 2-oxidase (P2Ox; pyranose:oxygen 2-oxidoreductase; EC 1.1.3.10) is a member of the glucose-methanol-choline (GMC) oxidoreductase family of flavin adenine dinucleotide (FAD)-dependent sugar oxidoreductases [1]. Typically, it is a homotetrameric enzyme of $\sim 265-270 \mathrm{kDa}[1]$ that is frequently found in wood-

\footnotetext{
* Correspondence: dietmar.haltrich@boku.ac.at

'Food Biotechnology Laboratory, Department of Food Science and Technology, BOKU University of Natural Resources and Life Sciences, Vienna, Austria
}

degrading basidiomycetes [2-4]. P2Ox is located in the periplasmic space and released extracellularly in later stages of development of the fungal cultures [5,6]. The enzyme was first isolated from Polyporus obtusus [7], and since then from several other, mainly lignocellulosedegrading, white-rot or brown-rot basidiomycetes including Phanerochaete chrysosporium [8,9], Trametes (Coriolus) versicolor [10], Phlebiopsis gigantea [11], Pleurotus ostreatus [12], Tricholoma matsutake [13], Gloeophyllum trabeum [14], and Trametes multicolor 
(synonym $T$. ochracea), which is maybe the best studied pyranose oxidase to date [1,15-17].

The reaction catalyzed by $\mathrm{P} 2 \mathrm{Ox}$ is of the Ping Pong $\mathrm{Bi} \mathrm{Bi}$ type typically found in flavoprotein oxidoreductases $[18,19]$, and can be divided into two half reactions. In the first half reaction, the reductive halfreaction, an aldopyranose substrate reduces the flavin adenine dinucleotide (FAD) cofactor to yield $\mathrm{FADH}_{2}$ and 2-dehydroaldose (2-ketoaldose) as the result of oxidation of the sugar at position C-2 (Reaction 1). The second, ensuing half reaction, the oxidative halfreaction, involves re-oxidation of $\mathrm{FADH}_{2}$ by an electron acceptor such as oxygen (Reaction 2). During this oxidative half-reaction, a C-4a-hydroperoxyflavin intermediate is formed when oxygen is used, which is the first evidence of such an intermediate for a flavoprotein oxidase [19-21]. In addition, alternative electron acceptors such as benzoquinone can be used by pyranose oxidase instead of oxygen in the oxidative half-reaction (Reaction 3).

$$
\begin{aligned}
& \text { FAD }+ \text { aldopyranose } \rightarrow \mathrm{FADH}_{2}+2 \text { - keto-aldopyranose } \\
& \mathrm{FADH}_{2}+\mathrm{O}_{2} \rightarrow \mathrm{FAD}+\mathrm{H}_{2} \mathrm{O}_{2}
\end{aligned}
$$

$\mathrm{FADH}_{2}+$ benzoquinone $\rightarrow \mathrm{FAD}+$ hydroquinone

It has been proposed that one possible function of P2Ox could be the formation of hydrogen peroxide and thus the provision of this compound for peroxidases involved in lignin degradation. Pyranose oxidase could also function as an antimicrobial agent through its formation of $\mathrm{H}_{2} \mathrm{O}_{2}$ as has been proposed for the arbuscular mycorrhizal fungus Tricholoma matsutake [13]. As mentioned above, P2Ox can use various other electron acceptors including quinones, complexed metal ions and radicals $[9,17]$. Some of these alternative electron acceptors are better substrates for the enzyme than oxygen as judged from the catalytic efficiency, suggesting that $\mathrm{P} 2 \mathrm{Ox}$ may play a role in the reduction of quinones during the process of ligninolysis [22], but this has not been studied in any detail yet. This excellent reactivity of $\mathrm{P} 2 \mathrm{Ox}$ with alternative electron acceptors and a range of sugar substrates can be employed in various attractive applications. One possible field of application is as a bio-element in sensors and biofuel cells, where it could replace glucose oxidase, which is typically used but shows certain disadvantages. In these applications, the enzyme communicates with an electrode through small redox-active compounds or redox mediators, in a process referred to as mediated electron transfer (MET). Recently, it was shown that P2Ox can be electrically wired to graphite electrodes through the use of osmium redox polymers [23], ferrocenes or benzoquinone [24] molecules that also serve as electron acceptors for P2Ox. These mediators transfer electrons from the enzyme to the electrode thus allowing P2Ox to be used in biosensors or biofuel cells. P2Ox is also a biocatalyst with high potential for biotransformations of carbohydrates; applications in synthetic carbohydrate chemistry, clinical analytics and in bioprocesses have been reviewed [25]. Because of the applied interest in this oxidoreductase, knowledge on P2Ox from other sources than the traditional wood-degrading fungi is of interest. P2Ox from Lyophyllum shimeji (LsP2Ox) has been described as an antimicrobial protein effective against the rice blast fungus Magnaporthe grisea and sheath blight fungus Rhizoctonia solani in a recent patent [26], but has not been studied in detail to date. Lyophyllum shimeji is a mycorrhizal fungus, which grows in association with Japanese red pine and oak trees, and is cultivated commercially in Japan where it is known as 'hon-shimeji'.

In the present study, we report the heterologous expression of pyranose oxidase from Lyophyllum shi$m e j i$ (LsP2Ox) under the control of the T7 promotor in E. coli (Rosetta 2), and for the first time a detailed characterization of $\mathrm{P} 2 \mathrm{Ox}$ from this mycorrhizal fungus. In addition, $L s \mathrm{P} 2 \mathrm{Ox}$ is compared with respect to some of its biochemical properties important for various applied aspects, including its kinetic properties and stability, of this enzyme to two other well-studied pyranose oxidases from lignocellulose-degrading fungi, namely TmP2Ox from T. multicolor [17] and $P c \mathrm{P} 2 \mathrm{Ox}$ from $P$. chrysosporium [9].

\section{Results and Discussion}

\section{Heterologous expression of LsP2Ox-encoding cDNA}

In a previous study cloning and heterologous expression of $L s \mathrm{P} 2 \mathrm{Ox}$ in $E$. coli, using the $\mathrm{pQE} 30$ vector (Qiagen) under control of a T5 expression system, was reported by us [26]. However, expression levels given were low (34 U/L), as apparently a significant fraction of the recombinant protein accumulated in inclusion bodies. In order to improve the expression of active $L s \mathrm{P} 2 \mathrm{Ox}$, fulllength cDNA encoding $L s \mathrm{P} 2 \mathrm{Ox}$ was expressed in $E$. coli Rosetta 2 using a pET21a(+) expression vector. The nucleotide sequence of the $p 20 x$ cDNA contains an ORF of $1,857 \mathrm{bp}$ encoding a polypeptide of 619 amino acids. Two primers, based on the cDNA sequence and containing restriction sites for the in-frame ligation into the pET21a $(+)$ vector were designed, and used to re-amplify the cDNA and construct the expression vector with the $p 2 o x$ cDNA under control of the lactose-inducible T7 promoter. The resulting vector was transformed into E. coli Rosetta 2, and ampicillin- and chloramphenicolresistant clones were tested for $\mathrm{P} 2 \mathrm{Ox}$ activity after induction of $L s \mathrm{P} 2 \mathrm{Ox}$ expression. The clone with the 
highest activity was selected for further studies; when using this bacterial clone in small-scale expression experiments a maximal volumetric activity of $250 \mathrm{U} / \mathrm{L}$ was obtained after $68 \mathrm{~h}$ of cultivation in shaken flasks at an $\mathrm{A}_{600}$ of $\sim 10$. This corresponds to a value of approx. $130 \mathrm{mg}$ of active, soluble recombinant LsP2Ox per L medium as calculated from a specific activity of $1.92 \mathrm{U} / \mathrm{mg}$ of the homogenous enzyme. These fermentation yields compare well to the expression levels of other fungal $\mathrm{P} 2 \mathrm{Ox}$ in E. coli. Typical yields for recombinant P2Ox production under comparable conditions range from 50-100 $\mathrm{mg} / \mathrm{L}$ for P2Ox from Trametes spp. $[27,28]$ to $270 \mathrm{mg} / \mathrm{L}$ for $P c$ P2Ox [9]. Furthermore, the value of $250 \mathrm{U} / \mathrm{L}$ for $L s \mathrm{P} 2 \mathrm{Ox}$ is significantly higher than the previously reported value of $34 \mathrm{U} / \mathrm{L}$ obtained with a different expression system [26]. It should also be mentioned that when using the expression host $E$. coli BL21(DE3), which we routinely use for the expression of P2Ox of different basidiomycete origin $[9,29,30]$, results for active recombinant $L s \mathrm{P} 2 \mathrm{Ox}$ were significantly lower (data not given). E. coli Rosetta 2 is designed to enhance the expression of eukaryotic proteins containing codons rarely used in $E$. coli by supplying tRNAs for the codons AUA, AGG, AGA, CUA, CCC, GGA and CGG on an additional plasmid together with the chloramphenicol resistance marker. When analyzing the codons occurring in the gene encoding $L s \mathrm{P} 2 \mathrm{Ox}$ and comparison with the genes coding for $T m \mathrm{P} 2 \mathrm{Ox}$ and $P c \mathrm{P} 2 \mathrm{Ox}$ we found indeed that the above-mentioned codons occur more frequently in the $p 2 o x$ gene of L. shimeji (Table 1).

\section{Enzyme purification}

The $p 20 x \mathrm{cDNA}$ was fused in frame with a C-terminal $\mathrm{His}_{6}$-tag encoded by the expression vector. However, IMAC could not be used for purification since the bound recombinant protein could not be eluted from the chromatographic material even with $1 \mathrm{M}$ imidazole. Therefore, a two-step purification procedure

Table 1 Comparison of codon usage frequency for selected codons that are specifically supported by $E$. coli Rosetta 2 in the genes encoding pyranose oxidase from L. shimeji, T. multicolor and $P$. chrysosporium

\begin{tabular}{lllll}
\hline Codon & Amino acid & \multicolumn{3}{l}{ Frequency of codon used (per $\mathbf{1 0 0 0}$ codons) } \\
\hline & & LsP2Ox & TmP2Ox & PcP2Ox \\
\hline AGG & Arg & 11.31 & 4.81 & 4.82 \\
AGA & Arg & 4.85 & 0.00 & 1.61 \\
CGG & Arg & 8.08 & 4.81 & 1.61 \\
GGA & Gly & 25.85 & 14.42 & 8.04 \\
AUA & Ile & 3.23 & 1.60 & 1.61 \\
CUA & Leu & 6.46 & 1.60 & 0.00 \\
CCC & Pro & 19.39 & 16.03 & 32.15
\end{tabular}

The number of occurrence of the selected codons per 1000 codons is given http://www.ebioinfogen.com/biotools/codon-usage.htm. based on anion exchange chromatography and preparative native PAGE was established (Table 2). Overall, $L s \mathrm{P} 2 \mathrm{Ox}$ was purified 18.8 -fold from the crude cell extract to a specific activity of $1.92 \mathrm{U} / \mathrm{mg}$. The purification procedure yielded a bright yellow enzyme preparation that was apparently homogenous as judged by SDS-PAGE (Figure 1). As estimated from this PAGE, the $L s \mathrm{P} 2 \mathrm{Ox}$ subunit has a molecular mass of $\sim 68 \mathrm{kDa}$, which corresponds very well with the calculated theoretical mass of $68,488 \mathrm{Da}$. TmP2Ox and $P c \mathrm{P} 2 \mathrm{Ox}$ were purified to apparent homogeneity via their $\mathrm{His}_{6}$-tag by using IMAC as previously published $[9,31]$. Interestingly, the construction of the $\mathrm{C}$-terminal $\mathrm{His}_{6}$-tag was similar for the three enzymes compared, i.e., no extra spacer was added. Nevertheless, the purification of LsP2Ox via IMAC was not successful when using a similar protocol successfully applied for the Histagged proteins $P c \mathrm{P} 2 \mathrm{Ox}$ and $T m \mathrm{P} 2 \mathrm{Ox}$. Based on the

Table 2 Purification of pyranose oxidase from Lyophyllum shimeji

\begin{tabular}{lcc}
\hline Purification step & specific activity [U/mg] & purification factor [fold] \\
\hline Crude extract & 0.102 & 1 \\
AIEX & 0.727 & 7.1 \\
Native PAGE & 1.92 & 18.8 \\
\hline
\end{tabular}

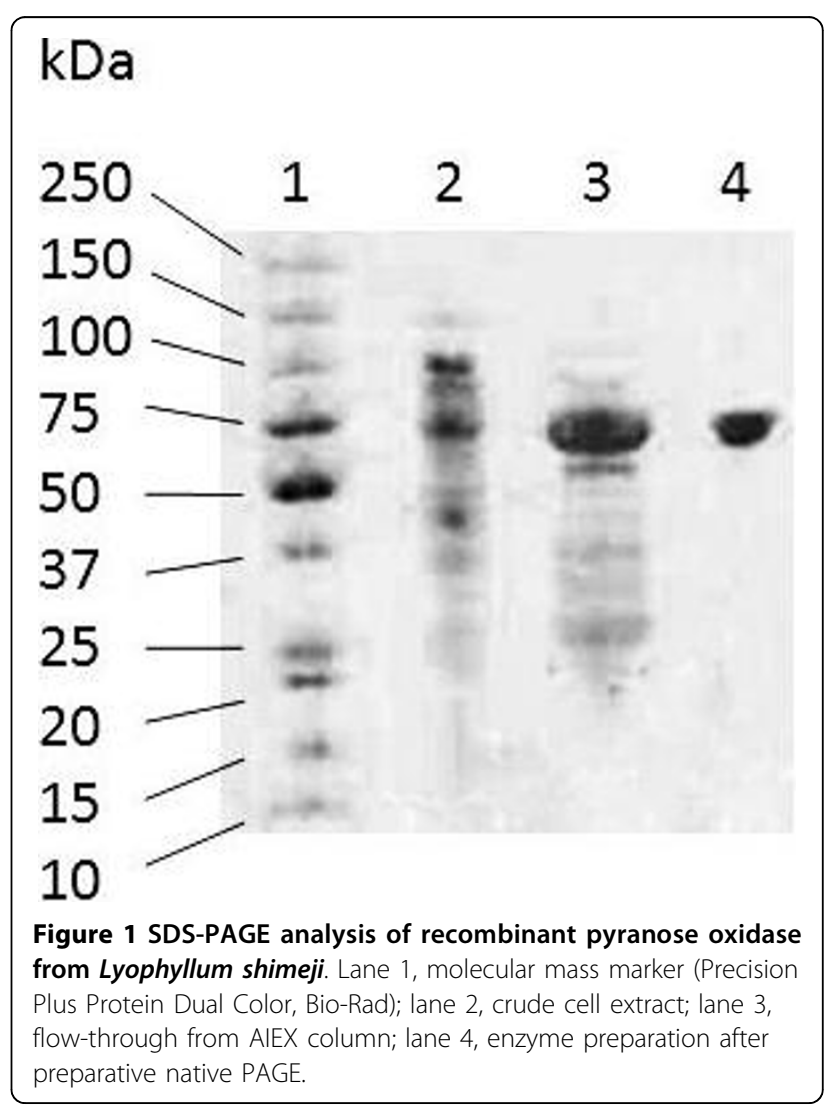


sequences of these three enzymes, a rational explanation for this behaviour is not possible. Since the protein also bound irreversibly to other standard chromatographic material used (data not shown), the reason could be through non-specific interactions of unidentified surface areas of the protein rather than the $\mathrm{His}_{6}$-tag.

\section{Kinetic properties}

An attractive feature of $\mathrm{P} 2 \mathrm{Ox}$ for various applications is its broad substrate specificity, both with respect to the electron donor and electron acceptor substrates. Therefore, the kinetic properties of $L s \mathrm{P} 2 \mathrm{Ox}$ (Michaelis constant $\mathrm{K}_{\mathrm{m}}$, catalytic constant $k_{\text {cat }}$, specificity constant $k_{\text {cat }} / \mathrm{K}_{\mathrm{m}}$ ) were determined for a range of different sugars and electron acceptors, and compared to the corresponding values determined for $\operatorname{Tm} \mathrm{P} 2 \mathrm{Ox}$ and $P c$ P2Ox. These latter two enzymes are both derived from lignocellulose-degrading basidiomycetes, and are among the best-studied pyranose oxidases to date. Kinetic constants for a range of electron donor substrates - various monosaccharides and the disaccharide melibiose - determined in the presence of air oxygen as saturating electron acceptor are summarised in Table 3. In general, $L s \mathrm{P} 2 \mathrm{Ox}$ is characterised by lower Michaelis constants as compared to those determined for $T m \mathrm{P} 2 \mathrm{Ox}$ and $P c \mathrm{P} 2 \mathrm{Ox}$, albeit also by catalytic

Table 3 Comparison of apparent kinetic constants of recombinant pyranose oxidase from Lyophyllum shimeji (LsP2Ox), Trametes multicolor (TmP2Ox) and Phanerochaete chrysosporium (PCP2Ox) for various electron donor substrates

\begin{tabular}{|c|c|c|c|c|c|}
\hline Enzyme & & $\mathrm{K}_{\mathrm{m}}[\mathrm{mM}]$ & $\begin{array}{l}k_{\text {cat }} \\
{\left[\mathrm{s}^{-1}\right]}\end{array}$ & $\begin{array}{c}k_{\mathrm{cat}} / \mathrm{K}_{\mathrm{m}} \\
{\left[\mathrm{mM}^{-1} \mathrm{~s}^{-1}\right]}\end{array}$ & $\begin{array}{l}\text { rel. } \boldsymbol{k}_{\text {cat }} / \\
\mathrm{K}_{\mathrm{m}}^{\mathrm{a}}[\%]\end{array}$ \\
\hline \multirow[t]{5}{*}{ LsP2Ox } & D-glucose & 0.314 & 6.92 & 22.1 & 100 \\
\hline & D-galactose & 3.84 & 1.02 & 0.265 & 100 \\
\hline & D-xylose & 6.30 & 5.48 & 0.867 & 100 \\
\hline & L-sorbose & 14.7 & 7.70 & 0.524 & 100 \\
\hline & melibiose & 72.8 & 0.839 & 0.0115 & 100 \\
\hline \multirow[t]{5}{*}{$\operatorname{TmP} 2 \mathrm{Ox}$} & D-glucose & 0.698 & 35.4 & 50.8 & 230 \\
\hline & D-galactose & 8.09 & 2.73 & 0.337 & 127 \\
\hline & D-xylose & 22.2 & 17.8 & 0.804 & 92.7 \\
\hline & L-sorbose & 35.6 & 31.6 & 0.887 & 169 \\
\hline & melibiose & 759 & 5.25 & 0.00691 & 60.1 \\
\hline \multirow[t]{5}{*}{ PCP2Ox } & D-glucose ${ }^{b}$ & 0.84 & 83.1 & 98.9 & 448 \\
\hline & D-galactose $e^{b}$ & 2.94 & 4.87 & 1.66 & 626 \\
\hline & D-xylose $e^{b}$ & 20.9 & 44.9 & 2.15 & 248 \\
\hline & L-sorbose ${ }^{b}$ & 23.5 & 58.8 & 2.50 & 477 \\
\hline & melibiose & 124.8 & 2.35 & 0.0189 & 164 \\
\hline
\end{tabular}

${ }^{a}$ catalytic efficiency $k_{\text {cat }} / K_{m}$ relative to the value calculated for $L s P 2 O x$ ${ }^{\mathrm{b}}$ data taken from reference [9]

Kinetic data were determined at $30^{\circ} \mathrm{C}, \mathrm{pH} 6.5$ and using oxygen (air saturation) as electron acceptor. constants that are significantly lower for these sugar substrates than those measured for the other two enzymes. D-Glucose is the favoured substrate for all three enzymes as judged by the catalytic efficiencies, while the disaccharide melibiose is the poorest, mainly because of a very unfavourable Michaelis constant. This unfavourable binding may be explained by a rather narrow active site of $\mathrm{P} 2 \mathrm{Ox}$ with the access being restricted by the active-site loop [16]. Similarly, kinetic constants were determined for $L s \mathrm{P} 2 \mathrm{Ox}$, $T m P 2 O x$ and PcP2Ox for the one-electron non-proton acceptor ferrocenium ion $\mathrm{Fc}^{+}$(ferrocenium hexafluorophosphate $\mathrm{FcPF}_{6}$ ) and the two-electron proton acceptors 1,4-benzoquinone (BQ) and 2,6-dichloroindophenol (DCIP) at a saturating concentration of $100 \mathrm{mM}$ D-glucose (Table 4). Again, LsP2Ox shows lower $\mathrm{K}_{\mathrm{m}}$ as well as lower $k_{\mathrm{cat}}$ values for these electron acceptors compared to TmP2Ox and PcP2Ox. Judged by the catalytic efficiencies, $B Q$ is the preferred substrate for all three enzymes.

The substrate specificity as well as kinetic properties of recP2Ox from L. shimeji described here are in overall agreement with those reported for P2Ox isolated from white-rot fungi. $L s \mathrm{P} 2 \mathrm{Ox}$ is, however, generally characterised by significantly lower catalytic constants $k_{\text {cat }}$ as well as by decreased Michaelis constants $K_{m}$ for most of these substrates when compared to TmP2Ox and PcP2Ox. Recently, we published the structure of $T m \mathrm{P} 2 \mathrm{Ox}$ ligated with a bound, poor substrate, 2-deoxy2-fluoro-D-glucose [16]. This structural analysis allowed the identification of active-site residues that directly take part in substrate binding. These residues include (in

Table 4 Comparison of apparent kinetic constants of recombinant pyranose oxidase from Lyophyllum shimeji (LsP2Ox), Trametes multicolor (TmP2Ox) and Phanerochaete chrysosporium (PcP2Ox) for the electron acceptor substrates ferrocenium ion $\left(\mathrm{Fc}^{+}\right), 1,4-$ benzoquinone (BQ) and 2,6-dichloroindophenol (DCIP)

\begin{tabular}{llllcc}
\hline Enzyme & & $\begin{array}{c}\mathbf{K}_{\mathbf{m}} \\
{[\mathbf{m M}]}\end{array}$ & $\begin{array}{c}\boldsymbol{k}_{\text {cat }} \\
{\left[\mathbf{s}^{-1}\right]}\end{array}$ & $\begin{array}{c}\boldsymbol{k}_{\text {cat }} / \mathbf{K}_{\mathbf{m}} \\
{\left[\mathbf{m M}^{-1} \mathbf{s}^{-1}\right]}\end{array}$ & $\begin{array}{c}\text { rel. } \boldsymbol{k}_{\text {cat }} / \\
\mathbf{K}_{\mathbf{m}}{ }^{\mathbf{a}}[\%]\end{array}$ \\
\hline LsP2Ox & $\mathrm{FC}^{+}$ & 0.187 & 39.9 & 213 & 100 \\
& $\mathrm{BQ}$ & 0.033 & 92.3 & 2760 & 100 \\
& $\mathrm{DCIP}$ & 0.187 & 67.3 & 361 & 100 \\
\hline TmP2Ox & $\mathrm{FC}^{+}$ & 0.507 & 291 & 574 & 269 \\
& $\mathrm{BQ}$ & 0.253 & 225 & 895 & 32.4 \\
& $\mathrm{DCIP}$ & 0.413 & 42.0 & 102 & 28.2 \\
\hline PCP2Ox & $\mathrm{FC}^{+}$ & 0.330 & 228 & 691 & 324 \\
& $\mathrm{BQ}$ & 0.110 & 400 & 3640 & 132 \\
& $\mathrm{DCIP}^{\mathrm{b}}$ & 0.051 & 108 & 2120 & 587 \\
\hline
\end{tabular}

${ }^{a}$ catalytic efficiency $k_{\text {cat }} / K_{m}$ relative to the value calculated for $L s P 2 O x$ ${ }^{b}$ data taken from reference [9]

Kinetic data were determined at $30^{\circ} \mathrm{C}, \mathrm{pH} 6.5$ and using D-glucose $(100 \mathrm{mM})$ as saturating electron donor. 
TmP2Ox numbering, corresponding positions for LsP2Ox are given in brackets) Gln448 (Gln441), Asp452 (Asp445), Arg472 (Arg465), His548 (His540), and Asn593 (Asn583). As shown in a sequence alignment, these active-site residues are strictly conserved for LsP2Ox, TmP2Ox and PcP2Ox (Figure 2). The only exception to this is found at Val546 in TmP2Ox, which corresponds to Ala538 and Ala551 in LsP2Ox and $P c \mathrm{P} 2 \mathrm{Ox}$, respectively. At this position, the interaction with the sugar substrate is through the carbonyl oxygen of the polypeptide main chain, forming a hydrogen bond with the $\mathrm{C} 1$ hydroxyl group of the sugar substrate, rather than through the amino acid side chain; hence the replacement of one hydrophobic aliphatic amino acid with another one should neither affect this interaction nor the properties of the active site. Furthermore, it was shown that the active-site loop ${ }^{450} \mathrm{His}-\mathrm{Val}^{459}$ is important for substrate recognition and catalysis $[1,16]$. This active-site loop is also strictly conserved in LsP2Ox $\left({ }^{443} \mathrm{HRDAFSY}\right.$ $\mathrm{GAV}^{452}$ ) when compared to both TmP2Ox and PcP2Ox as is evident from Figure 2. In addition, the residues His548 (His540), Asn593 (Asn583), Thr169 (Thr172) and His167 (His170) were shown to be important for catalysis and covalent binding of the prosthetic group $[1,16,20]$. Again, these residues are conserved (Figure 2). Because of this strict conservation of important active-site residues, the differences observed in catalytic properties of LsP2Ox must stem from subtle structural variations of the active site. Whether these differences are typically distinguishing P2Ox of ectomycorrhizal and white-rot fungal origin cannot be answered to date, and more pyranose oxidases from ectomycorrhizal fungi have to be studied to answer this question.

\section{$\mathrm{pH}$ dependence of activity}

$\mathrm{pH} /$ activity profiles were determined for the electron acceptors oxygen, DCIP, $\mathrm{Fc}^{+}$and $\mathrm{BQ}$ from $\mathrm{pH} 2.0$ to 10.0 for recombinant $L s \mathrm{P} 2 \mathrm{Ox}, T m \mathrm{P} 2 \mathrm{Ox}$ and $P c \mathrm{P} 2 \mathrm{Ox}$ (Figure 3). These profiles are well comparable for the three enzymes studied. The profiles for both oxygen and $\mathrm{BQ}$ are rather broad with bell-shaped curves, showing more than $80 \%$ activity in the range of $\mathrm{pH} 5.0$ to 7.0. In contrast, activity with DCIP shows a strong dependence on the $\mathrm{pH}$ with a sharp optimum of 5.0 for $L s \mathrm{P} 2 \mathrm{Ox}$ and $P c \mathrm{P} 2 \mathrm{Ox}$, and a somewhat lower optimum of 4.0-5.0 for TmP2Ox. P2Ox activity almost linearly increased with increasing $\mathrm{pH}$ for $\mathrm{Fc}^{+}$in the range of $\mathrm{pH} 2$ to 8 , regardless of its source. The three enzymes furthermore showed higher activity in the presence of borate buffer, which has not been shown previously. Artolozaga et al. showed that other buffer systems used at a comparable alkaline $\mathrm{pH}$ range (Tris- $\mathrm{HCl}$ buffer, Glycine- $\mathrm{NaOH}$ buffer) did not show a comparable effect [8].

\section{Thermal stability}

Pyranose oxidase from L. shimeji was investigated by differential scanning calorimetry and compared to the enzymes from $T$. multicolor and $P$. chrysosporium in order to study heat-induced unfolding and thus thermodynamic stability [32]. Cooperative unfolding peaks were observed in the first heating cycle (Figure 4). Samples showed significant protein precipitation after this first heating cycle, indicating irreversible aggregation, and hence no cooperative melting peaks were observed in a second heating cycle. Because of this, the thermodynamic values associated with the heat absorption data, which are calculated by equations that are based on reversible thermodynamic criteria, are only indicative. The measured values for the melting temperature $T_{\mathrm{m}}$, however, can be regarded as informative since irreversible aggregation occurs only once the unfolding process is complete, after reaching the melting point of the respective protein. These melting temperatures $T_{\mathrm{m}}$ determined are $54.9^{\circ} \mathrm{C}$ for $L s \mathrm{P} 2 \mathrm{Ox}$, while $T m \mathrm{P} 2 \mathrm{Ox}$ and PcP2Ox have $T_{\mathrm{m}}$ values of $58.2^{\circ} \mathrm{C}$ and $75.4^{\circ} \mathrm{C}$, respectively, indicating that $L s \mathrm{P} 2 \mathrm{Ox}$ is the least thermostable of the three enzymes compared.

To further investigate thermal stability, kinetic stabilities (i.e., the length of time an enzyme remains active before undergoing irreversible inactivation; [32]) were determined at different temperatures $\left(40\right.$ and $\left.50^{\circ} \mathrm{C}\right)$ and $\mathrm{pH}$ values ( $\mathrm{pH} 4.0,6.5,8.0)$ for the three $\mathrm{P} 2 \mathrm{Ox}$ samples. Again, $L s \mathrm{P} 2 \mathrm{Ox}$ shows the least stability when compared to TmP2Ox and PcP2Ox (Figure 5). While these enzymes show little inactivation at $40^{\circ} \mathrm{C}$ and $\mathrm{pH} 6.5$ and 8.0 (half-life times $\tau_{1 / 2}$ of approximately $60 \mathrm{~h}$ for $L s \mathrm{P} 2 \mathrm{Ox}$ ), inactivation is more pronounced at $\mathrm{pH} 4.0$, especially for $L s \mathrm{P} 2 \mathrm{O}$ which shows a half-life time $\tau_{1 / 2}$ of $43 \mathrm{~min}$ at this temperature. A more detailed analysis of the inactivation kinetics at $50^{\circ} \mathrm{C}$ is shown in Table 5 . Again, $P c$ P2Ox proved to be the most stable of the enzymes compared, and significant differences in thermal stability were found for the different enzymes. All three enzymes were inactivated most rapidly at $\mathrm{pH} 4.0$, with $\tau_{1 / 2}$ values ranging from 0.59 to $430 \mathrm{~min}$, and were found to be most stable at $\mathrm{pH} 6.5\left(\tau_{1 / 2}\right.$ values ranging from 0.12 to $96 \mathrm{~h}$ ).

$L s \mathrm{P} 2 \mathrm{Ox}$ was found to be less thermostable than $T m \mathrm{P} 2 \mathrm{Ox}$ and $\mathrm{PcP} 2 \mathrm{Ox}$, both when using DSC/melting temperature and inactivation kinetics as a measure for thermostability. The melting temperature $T_{\mathrm{m}}$ was $3^{\circ} \mathrm{C}$ lower than that found for $\operatorname{TmP} 2 \mathrm{Ox}$, while it was more than $20^{\circ} \mathrm{C}$ lower compared to $P c \mathrm{P} 2 \mathrm{Ox}$. These differences are also reflected in the $\tau_{1 / 2}$ values, the half-life times of activity, at $50^{\circ} \mathrm{C}$ and $\mathrm{pH} 6.5$, which are approx. 10-fold higher for TmP2Ox and 800-fold higher for PcP2Ox. As judged from thermostability and kinetic data, pyranose oxidase from $P$. chrysosporium seems to be the clearly 







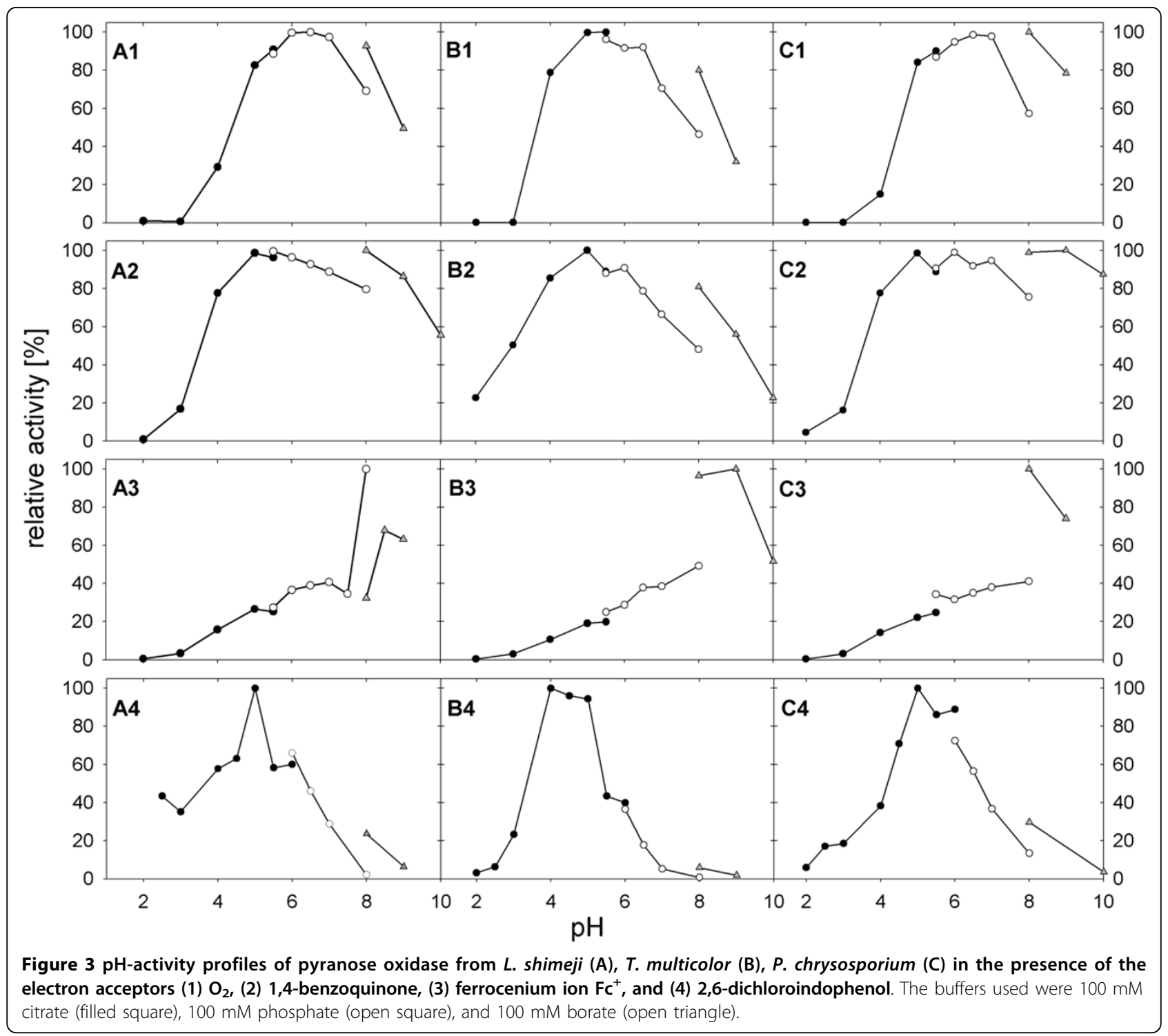

better suited biocatalyst for various biotechnological applications when compared to $L s \mathrm{P} 2 \mathrm{Ox}$ and TmP2Ox.

\section{Conclusions}

The enzyme pyranose oxidase has gained increased attention during the last years because of a number of attractive applications that have been proven or proposed for this enzyme. $\mathrm{P} 2 \mathrm{Ox}$ is a unique biocatalyst for a number of uses in carbohydrate transformations, converting simple sugars or sugar derivatives into valuable intermediates that can be further used for the synthesis of rare sugars, fine chemicals or pharmaceuticals [25]. Recently, it was shown that P2Ox can be used conveniently as an anodic component in biofuel cells, replacing glucose oxidase (GOx), which traditionally is used in these applications [23,24]. P2Ox offers several advantages over GOx for this use, e.g., its much broader substrate specificity is opening the possibility of utilising additional carbohydrates for these applications. Because of this renewed interest in P2Ox, knowledge on novel pyranose oxidases isolated from organisms other than white-rot fungi, which represent the traditional source of this enzyme, is of importance, as these novel enzymes might differ in their biochemical and physical properties. Furthermore, this knowledge on a variety of pyranose oxidases and their characteristics can be used for tailoring the properties of $\mathrm{P} 2 \mathrm{Ox}$, e.g., by combinatorial methods of directed evolution such as DNA shuffling. In this approach of enzyme engineering, two or more genes from different sources are the starting point for the engineering work [33]. This method allows the generation of a much larger spectrum of diversity than by 


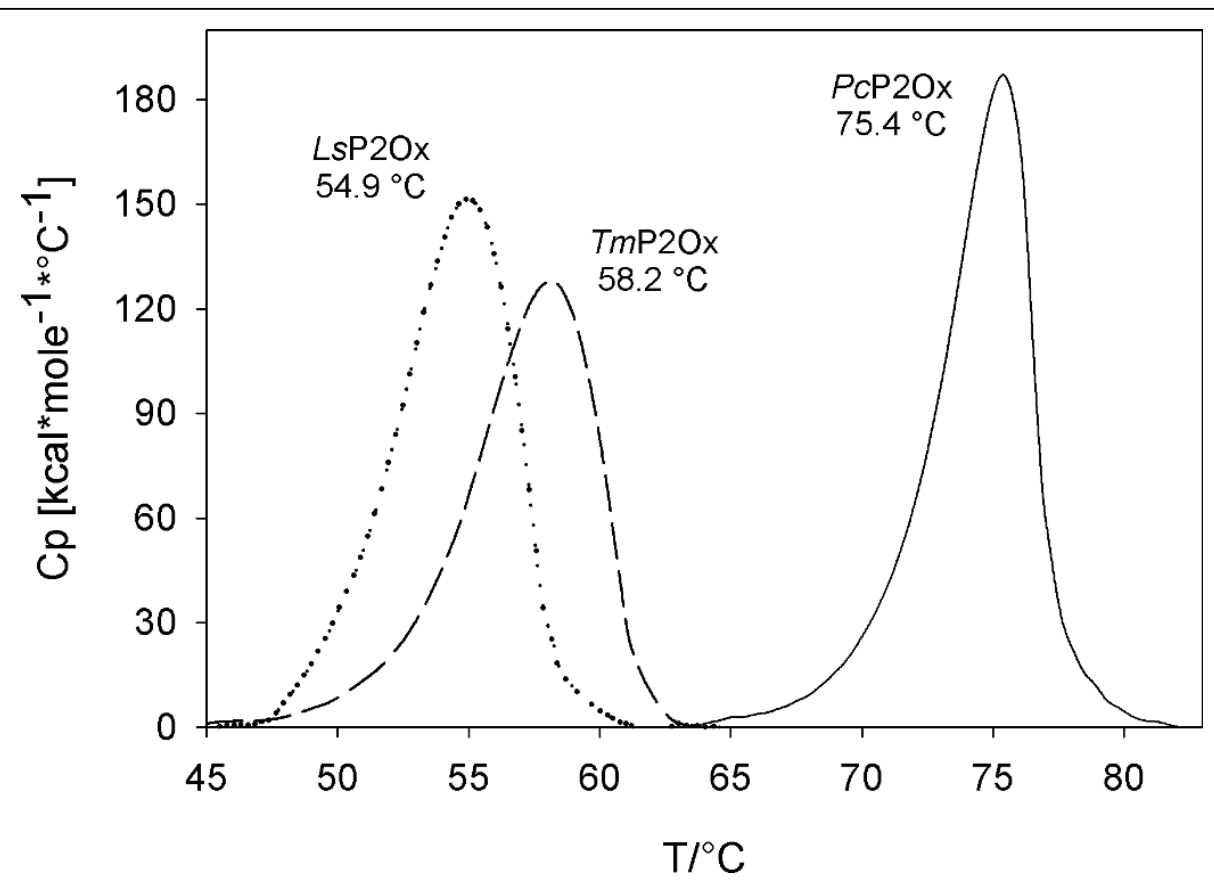

Figure 4 Denaturing thermograms determined by differential scanning calorimetry of pyranose oxidase from L. shimeji (LsP2Ox; dotted line); T. multicolor (TmP2Ox; dashed line), and P. chrysosporium (PcP2Ox, solid line).

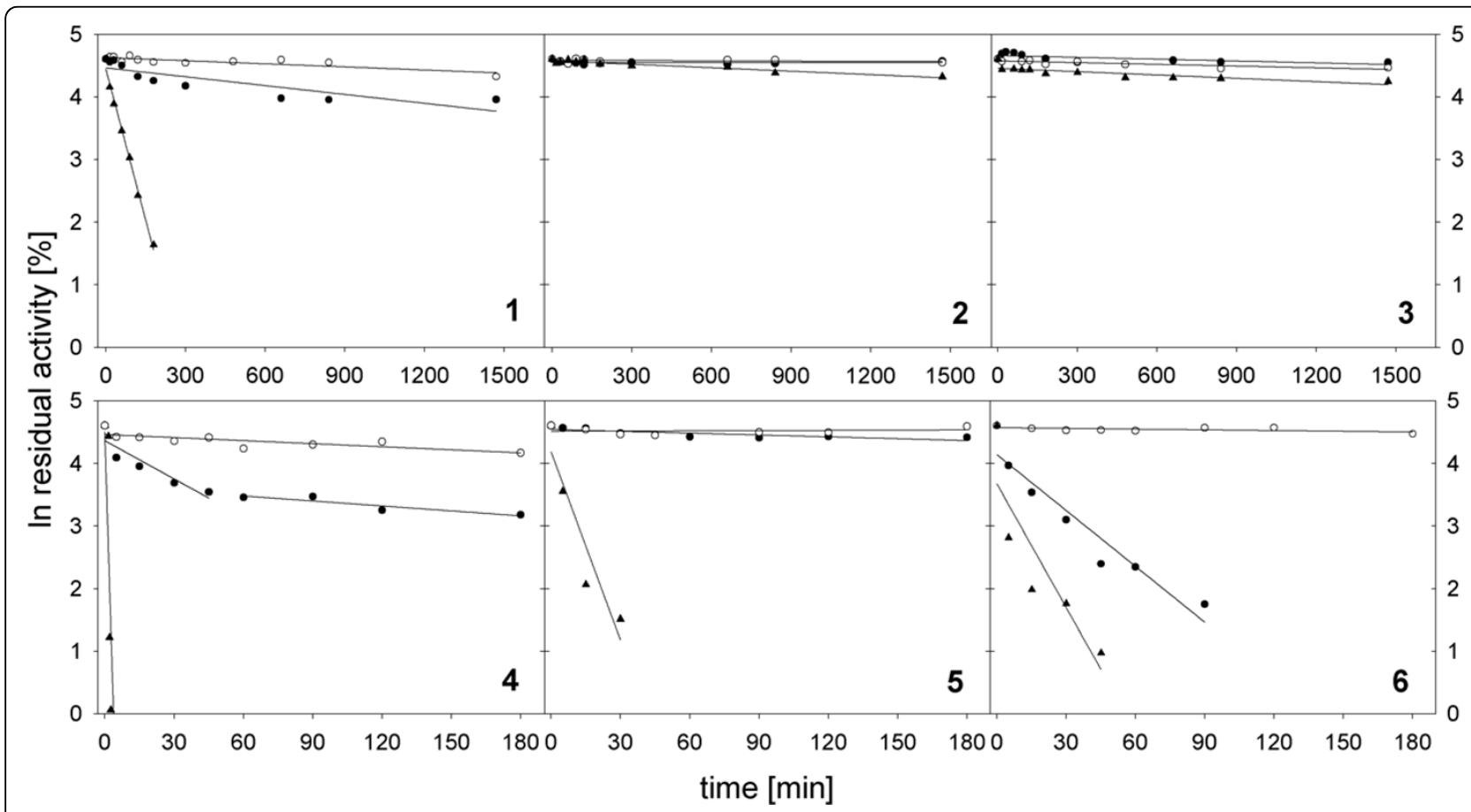

Figure 5 Inactivation kinetics of pyranose oxidase from L. shimeji (filled triangle), T. multicolor (filled square) and $P$. chrysosporium (open square) at $\mathbf{4 0} 0^{\circ} \mathbf{C}(1-3)$ and $50^{\circ} \mathbf{C}(4-6)$. Samples were incubated at pH $4.0(1,4), \mathrm{pH} 6.5(2,5)$, and pH $8.0(3,6)$. 
Table 5 Kinetic stability of recombinant pyranose oxidase from Lyophyllum shimeji (LsP20x), Trametes multicolor (TmP2Ox) and Phanerochaete chrysosporium (PcP2Ox) determined at $50^{\circ} \mathrm{C}$ and various pH values

\begin{tabular}{|c|c|c|c|c|c|c|}
\hline \multirow[b]{2}{*}{ Enzyme } & \multicolumn{2}{|l|}{$\mathrm{pH} 4.0$} & \multicolumn{2}{|l|}{$\mathrm{pH} 6.5$} & \multicolumn{2}{|l|}{ pH 8.0} \\
\hline & $\begin{array}{r}\text { inactivation constant } \\
k_{\text {in }}\left[\mathrm{min}^{-1}\right] \\
\end{array}$ & $\begin{array}{r}\text { half-life } \\
\tau_{1 / 2} \text { [min] } \\
\end{array}$ & $\begin{array}{r}\text { inactivation constant } \\
k_{\text {in }}\left[\mathrm{min}^{-1}\right] \\
\end{array}$ & $\begin{array}{r}\text { half-life } \\
\tau_{1 / 2} \text { [min] }\end{array}$ & $\begin{array}{r}\text { inactivation constant } \\
k_{\text {in }}\left[\mathrm{min}^{-1}\right] \\
\end{array}$ & $\begin{array}{r}\text { half-life } \\
\tau_{1 / 2} \text { [min] }\end{array}$ \\
\hline LsP2Ox & $11800 \times 10^{-4}$ & 0.587 & $1000 \times 10^{-4}$ & 6.92 & $659 \times 10^{-4}$ & $\overline{10.5}$ \\
\hline TmP2Ox & $204 \times 10^{-4}$ & 33.9 & $98.6 \times 10^{-4}$ & 70.3 & $297 \times 10^{-4}$ & 23.3 \\
\hline PCP2Ox & $16.3 \times 10^{-4}$ & 433 & $1.20 \times 10^{-4}$ & 5760 & $3.85 \times 10^{-4}$ & 1800 \\
\hline
\end{tabular}

natural recombination or mutational mechanisms, since two or more homologues from multiple species in different ratios are used for recombination [34,35]. Recently, we could show that various approaches of semi-rational design can significantly improve the properties of $T m \mathrm{P} 2 \mathrm{Ox}$ for applications in biofuel cells, e.g. by increasing thermostability [31] or catalytic properties with respect to various electron acceptor substrates [36], making it possible to achieve a higher energy output of an enzymatic biofuel cell when using the same concentration of sugar substrate [24], and hence a combinatorial engineering approach would certainly be worthwhile for further improvements of pyranose oxidase.

In this study we report the detailed characterization of a P2Ox from the ectomycorrhizal basidiomycete Lyophyllum shimeji. Relatively little is known about enzyme activities of ectomycorrhiza involved in the metabolism of lignin. Genes equivalent to various peroxidases such as lignin peroxidase and manganese peroxidase as found in wood-degrading white-rot fungi appear to be widespread in ectomycorrhizal basidiomycetes $[37,38]$, but the corresponding gene products have not been studied in detail so far. Laccase, along with a range of related phenol-oxidising activities, which is also thought to play an important role in lignin degradation, has also been reported in several ectomycorrhizal fungi [27,28,39], but again the corresponding enzymes have not been studied in detail pertaining to their biochemical properties. Hence, the study of enzymes related to ligninolysis such as pyranose oxidase - and derived from ectomycorrhizal basidiomycetes is also of fundamental interest.

Pyranose oxidase from $L$. shimeji is very similar to P2Ox isolated from wood-degrading white-rot fungi such as $P$. chrysosporium or $T$. multicolor with respect to its physical and biochemical properties. P2Ox has been speculated to be an important source of hydrogen peroxide, which is an essential co-substrate for peroxidases. As judged from the biochemical similarities of LsP2Ox with pyranose oxidases from white-rot sources, the enzyme could play a similar role in ectomycorrhizal fungi, supplying peroxidases with hydrogen peroxide.

Whether the differences observed for P2Ox from ectomycorrhizal L. shimeji and the white rotters T. multicolor and P. Phanerochaete, e.g. pertaining to kinetic properties or stability, are typically distinguishing P2Ox of ectomycorrhizal and white-rot fungal origin cannot be answered to date, as more pyranose oxidases from ectomycorrhizal fungi will have to be studied to answer this question unequivocally.

\section{Methods}

\section{Organisms and plasmids}

P2Ox from T. multicolor and P. chrysosporium were heterologously expressed in E. coli BL21(DE3) (Fermentas; St. Leon-Roth, Germany) using the pET21-d(+) and pET21-a(+) expression vector (Novagen; Madison, WI), respectively $[9,16]$. The recombinant enzymes were fused with a $\mathrm{C}$-terminal $\mathrm{His}_{6}$-tag for one-step purification via immobilized metal affinity chromatography (IMAC). Construction of the LsP2Ox cDNA in the pBluescript vector (Stratagene; La Jolla, CA) was recently reported [26]. Briefly, L. shimeji fruiting bodies were obtained from Shiga Forest Research Center (Yasu-shi, Japan). From these fruiting bodies a cDNA library was constructed and $L s \mathrm{P} 2 \mathrm{Ox}$ cDNA was isolated.

\section{Cloning of P2Ox from Lyophyllum shimeji}

The LsP2Ox cDNA sequence was amplified by PCR using two modified flanking primers based on the nucleotide sequence (GenBank accession number AB119106), and containing a HindIII and NotI restriction site: LSHindIII_fwd: 5'-AAGCTTATGTCTCTCTCAACCGAGCAG-3' and LSNotI_rev: 5'-GCGGCCG CAAGGTTGCGATGCTCGCCTG-3'. The amplified sequence was temporarily cloned blunt into the pJET vector using the pJET Cloning Kit (Fermentas). The gene was excised and ligated into the pET21a(+) expression vector in frame with the C-terminal $\mathrm{His}_{6}$-tag; this tag was added directly at the C-terminus without the insertion of an additional spacer. This plasmid was then transformed and $L s \mathrm{P} 2 \mathrm{Ox}$ heterologously expressed in E. coli Rosetta 2(DE3)pLacI (Novagen).

\section{Cultivation and expression of P2Ox}

Cultivation of E. coli Rosetta 2 and BL21(DE3) for production of recombinant enzymes was done in $\mathrm{TB}$ medium $(24 \mathrm{~g} / \mathrm{L}$ yeast extract, $12 \mathrm{~g} / \mathrm{L}$ peptone from casein, $4 \mathrm{~mL} / \mathrm{L}$ glycerol, $1 \mathrm{M}$ potassium phosphate 
buffer $\mathrm{pH}$ 7.5). E. coli Rosetta 2 (for over-expression of $L s \mathrm{P} 2 \mathrm{Ox}$ ) was pre-cultivated in $25 \mathrm{~mL}$ of TB-medium containing $100 \mu \mathrm{g} / \mathrm{mL}$ ampicillin and $34 \mu \mathrm{g} / \mathrm{mL}$ chloramphenicol. E. coli BL21(DE3) (for PcP2Ox, TmP2Ox) was pre-grown in shaken flasks using $25 \mathrm{~mL}$ of TB medium and $100 \mu \mathrm{g} / \mathrm{mL}$ ampicillin. After $4 \mathrm{~h}$ of growth the cell suspensions were transferred into baffled shaken flasks containing $250 \mathrm{~mL}$ of the respective medium and $0.5 \%$ lactose for induction of recombinant protein expression. Cultures were incubated at $18^{\circ} \mathrm{C}, 110 \mathrm{rpm}$ and $68 \mathrm{~h}$ for $E$. coli Rosetta 2, and $25^{\circ} \mathrm{C}, 110 \mathrm{rpm}$ and $24 \mathrm{~h}$ for $E$. coli BL21(DE3). Cells were harvested by centrifugation for $15 \mathrm{~min}$ at $10,000 \times g$ and $4^{\circ} \mathrm{C}$, the pellets were resuspended in a threefold volume of the buffer used for the subsequent enzyme purification procedure, and cells were disrupted in a continuous homogenizer (APV Systems; Silkeborg, Denmark) after adding phenyl methyl sulfonyl fluoride (PMSF; $1 \mathrm{~g} / \mathrm{L}$ ) as a protease inhibitor. The homogenates were clarified by ultracentrifugation at $35,000 \times g$ for $30 \mathrm{~min}$ at $4{ }^{\circ} \mathrm{C}$, and the recombinant proteins were purified from these crude cell extracts [40].

\section{Enzyme purification}

Even though LsP2Ox was His-tagged, it could not be purified by IMAC as it irreversibly bound onto the $\mathrm{Ni}^{2+}$ column used $\left(\mathrm{Ni}^{2+}\right.$-charged Chelating Sepharose Fast Flow; Amersham Pharmacia, Uppsala, Sweden). Hence, a two-step purification process was established for LsP2Ox using anionic exchange chromatography (AIEX) and preparative native PAGE. AIEX was done on a 450$\mathrm{mL}$ Q-Sepharose (Amersham Pharmacia) column preequilibrated with Buffer A $50 \mathrm{mM} 2-(\mathrm{N}$-morpholino) ethanesulfonic acid (MES), $50 \mathrm{mM} \mathrm{NaCl}, \mathrm{pH}$ 6.0]. After applying the crude extract to the column and washing with Buffer A, LsP2Ox was collected in the flow-through while protein contamination from the crude extract bound to the chromatographic material. The active fractions of the flow-through were concentrated by ultrafiltration using an Amicon Ultra Centrifugal Filter Device with a $10-\mathrm{kDa}$ cut-off membrane (Millipore; Billerica, MA), and loaded onto a preparative native gel (10\% acrylamide, $0.2 \%$ ammonium persulfate, $0.2 \%$ Temed). After running the Native PAGE, LsP2Ox was detected by active staining. One lane of the gel was covered with a layer of the reagent normally used in the standard chromogenic ABTS assay (see below) for the spectrophotometrical enzyme activity determination. The active protein band was identified by its green colour, and LsP2Ox could be extracted from the remaining lanes with potassium-phosphate buffer (50 mM, pH 6.5). $T m \mathrm{P} 2 \mathrm{Ox}$ and $P c \mathrm{P} 2 \mathrm{Ox}$ were purified by IMAC as previously reported [40]. In short, crude extracts were passed through a $100-\mathrm{mL} \mathrm{Ni}^{2+}$-immobilized column
(Chelating Sepharose Fast Flow; Amersham Pharmacia). After washing the column with Buffer B $(50 \mathrm{mM}$ $\mathrm{KH}_{2} \mathrm{PO}_{4}, \mathrm{pH} 6.5,0.5 \mathrm{M}$ sodium chloride) containing $20 \mathrm{mM}$ imidazole and applying the respective crude extracts, protein was eluted by a linear imidazole gradient of 20 to $1000 \mathrm{mM}$ imidazole in Buffer B. Active fractions were pooled and again concentrated by ultrafiltration as above.

SDS-PAGE was performed on a PhastSystem unit (Amersham Pharmacia) according to the manufacturer's instructions using precast gels (precast PhastGel, Gradient 8-25) and the Precision Plus Protein Dual Color Kit (Biorad) as molecular mass standard.

\section{Enzyme activity assay}

P2Ox activity was measured with the standard chromogenic 2,2'-azinobis(3-ethylbenzthiazolinesulfonic acid) (ABTS) assay [3]. A sample of diluted enzyme $(10 \mu \mathrm{L})$ was added to $980 \mu \mathrm{L}$ of assay buffer containing horseradish peroxidase $(5.72 \mathrm{U})$, ABTS $(0.59 \mathrm{mg})$ and phosphate buffer $(50 \mathrm{mM}, \mathrm{pH} 6,5)$. The reaction was started by adding $\mathrm{D}$-glucose $(20 \mathrm{mM})$. The absorbance change at $420 \mathrm{~nm}$ was recorded at $30^{\circ} \mathrm{C}$ for $180 \mathrm{~s}\left(\epsilon_{420}=43.2\right.$ $\left.\mathrm{mM}^{-1} \mathrm{~cm}^{-1}\right)$. Protein concentrations were determined by the Bradford assay using the Bio-Rad Protein Assay Kit with BSA as standard.

\section{Steady-state kinetic measurements}

Steady-state kinetic constants were measured for LsP2Ox, TmP2Ox and PcP2Ox for different electron donor (sugar) as well as electron acceptor substrates. Unless otherwise stated, all measurements were performed at $30^{\circ} \mathrm{C}$ in $50 \mathrm{mM}$ potassium phosphate buffer (pH 6.5). Measurements of kinetic constants for various sugar substrates were done with oxygen (air saturation) and the routine ABTS-peroxidase assay. D-Glucose, Dgalactose, D-xylose, L-sorbose and melibiose were varied over a range of 0.25-500 mM. Furthermore, kinetic constants for the electron acceptors 2,6-dichloroindophenol (DCIP), ferrocenium ion $\mathrm{Fc}^{+}$(using hexafluorophosphate $\mathrm{Fc}^{+} \mathrm{PF}_{6}^{-}$; Aldrich, Steinheim, Germany) and 1,4-benzoquinone $(\mathrm{BQ})$ were determined. These experiments were performed with a constant saturating D-glucose concentration of $100 \mathrm{mM}$. DCIP was varied over a range of 7.5 to $600 \mu \mathrm{M}$ and the time-dependent reduction was measured at $520 \mathrm{~nm}\left(\epsilon_{520}=6.8 \mathrm{mM}^{-1} \mathrm{~cm}^{-1}\right)$ [41]. Fc ${ }^{+}$was varied from 5 to $600 \mu \mathrm{M}$ and measured at $300 \mathrm{~nm}$ $\left(\epsilon_{300}=4.3 \mathrm{mM}^{-1} \mathrm{~cm}^{-1}\right)$, while BQ was varied from 10 to $750 \mu \mathrm{M}$ and measured at $290 \mathrm{~nm}\left(\epsilon_{290}=2.24 \mathrm{mM}^{-1} \mathrm{~cm}^{-1}\right)$. In short, $10 \mu \mathrm{L}$ of appropriately diluted enzyme was added to $990 \mu \mathrm{L}$ of buffer containing D-glucose and the electron acceptor substrate, and which had been flushed with nitrogen to remove oxygen. All the kinetic constants were calculated using non-linear least-squares regression by 
fitting the observed data to the Michaelis-Menten equation. Turnover numbers $\left(k_{\mathrm{cat}}\right)$ were calculated using a molecular mass of $68 \mathrm{kDa}$ for the P2Ox subunits.

\section{$\mathrm{pH}$ dependence of activity}

pH-activity profiles of $L s \mathrm{P} 2 \mathrm{Ox}, T m \mathrm{P} 2 \mathrm{Ox}$ and $P c \mathrm{P} 2 \mathrm{Ox}$ were determined for oxygen, DCIP $(0.3 \mathrm{mM}), \mathrm{Fc}^{+}(0.3$ $\mathrm{mM})$ and $\mathrm{BQ}(0.5 \mathrm{mM})$ in the range of $\mathrm{pH} 2.0$ to 10.0 , using the buffer system sodium citrate ( $\mathrm{pH}$ 2.0-6.0), potassium phosphate $(\mathrm{pH}$ 6.0-8.0) and sodium borate (pH 8.0-10.0), each at a concentration of $100 \mathrm{mM}$. Activity measurements were performed with a constant D-glucose concentration of $100 \mathrm{mM}$ at $30^{\circ} \mathrm{C}$.

\section{Thermal stability}

Kinetic stability of $L s \mathrm{P} 2 \mathrm{Ox}, T m \mathrm{P} 2 \mathrm{Ox}$ and $P c \mathrm{P} 2 \mathrm{Ox}$ was determined at 40 and $50^{\circ} \mathrm{C}$ and at $\mathrm{pH} 4.0,6.5$ and 8.0, using the same buffers as above. Samples were taken at various time points $t$ and $\mathrm{P} 2 \mathrm{Ox}$ activity $(A)$ was measured using the standard ABTS assay. A thermal cycler and thin-walled PCR tubes were used for all thermostability measurements. Residual activities $\left(A_{t} / A_{0}\right.$, where $A_{t}$ is the activity measured at time $t$ and $A_{O}$ is the initial activity at $t=0)$ were plotted versus the incubation time. Inactivation constants $k_{\text {in }}$ were obtained by linear regression of (ln activity) versus $t$. The half-life values of thermal inactivation $\tau_{1 / 2}$ were calculated using $\tau_{1 / 2}=\ln 2 / k_{\text {in }}$ [32].

Thermodynamic stability was measured by determination of the melting temperatures $T_{\mathrm{m}}$, using differential scanning calorimetry (DSC) and a MicroCal VP-DSC instrument (MicroCal, Northampton, MA) in the range of $20-100^{\circ} \mathrm{C}$ at a scan rate of $1^{\circ} \mathrm{C}$ per min on $4 \mu \mathrm{M}$ protein samples in $50 \mathrm{mM}$ phosphate buffer (pH 6.5). Samples were degassed by continuous stirring for $15 \mathrm{~min}$ in vacuum immediately before starting the measurements. For baseline correction a buffer blank was scanned in the second chamber and subtracted. Evaluation of data was performed by the Origin 7.5 software (OriginLab Corporation, Northampton, MA).

\section{List of abbreviations}

ABTS: 2,2'-azinobis(3-ethylbenzthiazolinesulfonic acid); BQ: 1,4-benzoquinone; DCIP: 2,6-dichloroindophenol; Fc ${ }^{+}$: ferrocenium ion; LsP2Ox: pyranose oxidase from Lyophyllum shimeji; P2Ox: pyranose oxidase; PcP2Ox: pyranose oxidase from Phanerochaete chrysosporium; $T_{\mathrm{m}}$ : melting temperature; TmP2Ox: pyranose oxidase from Trametes multicolor; $\tau_{1 / 2}$ : half-life times

\section{Competing interests}

The authors declare that they have no competing interests.

\section{Authors' contributions}

CS and BS carried out the molecular biology studies as well as the biochemical characterisation experiments of the enzyme and drafted the manuscript. YT and MT participated in the molecular biology studies as well as in the sequence alignment, and revised the draft. OS checked the data and revised the draft. MY co-supervised the molecular biology studies. CKP and IDH conceived of the study, and edited the manuscript. All authors read and approved the final manuscript.

\section{Acknowledgements}

Financial support from the Austrian Science Fund (FWF, Translational Projects L210-B11 and L213-B11) and the Competence Centre, Applied Biocatalysis' is gratefully acknowledged.

\section{Author details}

${ }^{1}$ Food Biotechnology Laboratory, Department of Food Science and Technology, BOKU University of Natural Resources and Life Sciences, Vienna, Austria. ${ }^{2}$ Research Centre Applied Biocatalysis, Graz, Austria. ${ }^{3}$ Plant Innovation Center, Japan Tobacco, Iwata, Shizuoka, Japan. ${ }^{4}$ School of Biotechnology, Suranaree University of Technology, Nakhon Ratchasima, Thailand.

Received: 17 March 2010 Accepted: 14 July 2010

Published: 14 July 2010

\section{References}

1. Hallberg BM, Leitner C, Haltrich D, Divne C: Crystal structure of the 270 $\mathrm{kDa}$ homotetrameric lignin-degrading enzyme pyranose 2-oxidase. $\mathrm{J} \mathrm{Mol}$ Biol 2004, 341:781-796.

2. Danneel H-J, Ullrich M, Giffhorn F: Goal-oriented screening method for carbohydrate oxidases produced by filamentous fungi. Enzyme Microb Technol 1992, 14:898-903.

3. Leitner C, Haltrich D, Nidetzky B, Prillinger H, Kulbe KD: Production of a novel pyranose 2-oxidase by basidiomycete Trametes multicolor. Appl Biochem Biotechnol 1998, 70-72:237-248.

4. Volc J, Denisova NP, Nerud F, Musilek V: Glucose-2-oxidase activity in mycelia cultures of basidiomycetes. Folia Microbiol 1985, 30:141-147.

5. Daniel G, Volc J, Kubátová E, Nilsson T: Ultrastructural and immunocytochemical studies on the $\mathrm{H}_{2} \mathrm{O}_{2}$-producing enzyme pyranose oxidase in Phanerochaete chrysosporium grown under liquid culture conditions. Appl Environ Microbiol 1992, 58:3667-3676.

6. de Koker TH, Mozuch MD, Cullen D, Gaskell J, Kersten PJ: Isolation and purification of pyranose 2-oxidase from Phanerochaete chrysosporium and characterization of gene structure and regulation. Appl Environ Microbiol 2004, 70:5794-5800

7. Ruelius HW, Kerwin RM, Janssen FW: Carbohydrate oxidase, a novel enzyme from Polyporus obtusus. I. Isolation and purification. Biochim Biophys Acta 1968, 167:493-500.

8. Artolozaga MJ, Kubátová E, Volc J, Kalisz HM: Pyranose 2-oxidase from Phanerochaete chrysosporium - further biochemical characterisation. Appl Microbiol Biotechnol 1997, 47:508-514.

9. Pisanelli I, Kujawa M, Spadiut O, Kittl R, Halada P, Volc J, Mozuch MD, Kersten $\mathrm{P}$, Haltrich D, Peterbauer C: Pyranose 2-oxidase from Phanerochaete chrysosporium-expression in E. coli and biochemical characterization. J Biotechnol 2009, 142:97-106.

10. Machida Y, Nakanishi T: Purification and properties of pyranose oxidase from Coriolus versicolor. Agric Biol Chem 1984, 48:2463-2470.

11. Schäfer A, Bieg S, Huwig A, Kohring GW, Giffhorn F: Purification by immunoaffinity chromatography, characterization, and structural analysis of a thermostable pyranose oxidase from the white rot fungus Phlebiopsis gigantea. Appl Environ Microbiol 1996, 62:2586-2592.

12. Shin KS, Youn HD, Han YH, Kang SO, Hah YC: Purification and characterization of D-glucose-oxidase from white-rot fungus Pleurotus ostreatus. Eur J Biochem 1993, 215:747-752.

13. Takakura $Y$, Kuwata S: Purification, characterization, and molecular cloning of a pyranose oxidase from the fruit body of the basidiomycete, Tricholoma matsutake. Biosci Biotechnol Biochem 2003, 67:2598-2607.

14. Dietrich D, Crooks C: Gene cloning and heterologous expression of pyranose 2-oxidase from the brown-rot fungus, Gloeophyllum trabeum. Biotechnol Lett 2009, 31:1223-1228.

15. Halada $P$, Leitner $C$, Sedmera $P$, Haltrich $D$, Volc J: Identification of the covalent flavin adenine dinucleotide-binding region in pyranose 2oxidase from Trametes multicolor. Anal Biochem 2003, 314:235-242.

16. Kujawa M, Ebner H, Leitner C, Hallberg BM, Prongjit M, Sucharitakul J, Ludwig R, Rudsander U, Peterbauer C, Chaiyen P, et al: Structural basis for substrate binding and regioselective oxidation of monosaccharides at C3 by pyranose 2-oxidase. J Biol Chem 2006, 281:35104-35115. 
17. Leitner C, Volc J, Haltrich D: Purification and characterization of pyranose oxidase from the white rot fungus Trametes multicolor. Appl Environ Microbiol 2001, 67:3636-3644.

18. Ghisla S, Massey V: Mechanisms of flavoprotein-catalyzed reactions. Eur J Biochem 1989, 181:1-17.

19. Prongjit M, Sucharitakul J, Wongnate $T$, Haltrich D, Chaiyen P: Kinetic mechanism of pyranose 2-oxidase from Trametes multicolor. Biochemistry 2009, 48:4170-4180.

20. Pitsawong W, Sucharitakul J, Prongjit M, Tan TC, Spadiut O, Haltrich D, Divne C, Chaiyen P: A conserved active-site threonine is important for both sugar and flavin oxidations of pyranose 2-oxidase. J Biol Chem 2010, 285:9697-9705

21. Sucharitakul J, Prongjit M, Haltrich D, Chaiyen P: Detection of a C4ahydroperoxyflavin intermediate in the reaction of a flavoprotein oxidase. Biochemistry 2008, 47:8485-8490.

22. ten Have R, Teunissen PJ: Oxidative mechanisms involved in lignin degradation by white-rot fungi. Chem Rev 2001, 101:3397-3413.

23. Tasca F, Timur S, Ludwig R, Haltrich D, Volc J, Antiochia R, Gorton L: Amperometric biosensors for detection of sugars based on the electrical wiring of different pyranose oxidases and pyranose dehydrogenases with osmium redox polymers on graphite electrodes. Electroanalysis 2007, 19:294-302.

24. Spadiut O, Brugger D, Coman V, Haltrich D, Gorton L: Engineered pyranose 2-oxidase: efficiently turning sugars into electrical energy. Electroanalysis 2010, 22:813-820.

25. Giffhorn F: Fungal pyranose oxidases: occurrence, properties and biotechnical applications in carbohydrate chemistry. Appl Microbiol Biotechnol 2000, 54:727-740.

26. Takakura Y, Kuwata S, Inouse Y: Antimicrobial protein from Lyophyllum shimeji. Japan Tobacco Inc 2007, US Patent 7232673.

27. Kotik M, Kocanova M, Maresova $H$, Kyslik P: High-level expression of a fungal pyranose oxidase in high cell-density fed-batch cultivations of Escherichia coli using lactose as inducer. Protein Expr Purif 2004, 36:61-69.

28. Maresova H, Palyzova A, Kyslik P: The C-terminal region controls correct folding of genus Trametes pyranose 2-oxidases. J Biotechnol 2007, 130:229-235.

29. Spadiut O, Radakovits K, Pisanelli I, Salaheddin C, Yamabhai M, Tan TC, Divne C, Haltrich D: A thermostable triple mutant of pyranose 2-oxidase from Trametes multicolor with improved properties for biotechnological applications. Biotechnol J 2009, 4:525-534.

30. Spadiut O, Posch G, Ludwig R, Haltrich D, Peterbauer CK: Evaluation of different expression systems for the heterologous expression of pyranose 2-oxidase from Trametes multicolor in E. coli. Microb Cell Fact 2010, 9:14.

31. Spadiut O, Leitner C, Salaheddin C, Varga B, Vertessy BG, Tan TC, Divne C, Haltrich D: Improving thermostability and catalytic activity of pyranose 2-oxidase from Trametes multicolor by rational and semi-rational design. FEBS J 2009, 276:776-792.

32. Polizzi KM, Bommarius AS, Broering JM, Chaparro-Riggers JF: Stability of biocatalysts. Curr Opin Chem Biol 2007, 11:220-225.

33. Songsiriritthigul C, Pesatcha P, Eijsink VG, Yamabhai M: Directed evolution of a Bacillus chitinase. Biotechnol J 2009, 4:501-509.

34. Farinas ET, Bulter T, Arnold FH: Directed enzyme evolution. Curr Opin Biotechnol 2001, 12:545-551.

35. Stemmer WP: DNA shuffling by random fragmentation and reassembly: in vitro recombination for molecular evolution. Proc Natl Acad Sci USA 1994, 91:10747-10751.

36. Spadiut O, Pisanelli I, Maischberger T, Peterbauer C, Gorton L, Chaiyen P, Haltrich D: Engineering of pyranose 2-oxidase: improvement for biofuel cell and food applications through semi-rational protein design. J Biotechnol 2009, 139:250-257.

37. Bodeker IT, Nygren CM, Taylor AF, Olson A, Lindahl BD: Classll peroxidaseencoding genes are present in a phylogenetically wide range of ectomycorrhizal fungi. ISME J 2009, 3:1387-1395.

38. Chen DM, Taylor AFS, Burke RM, Cairney JW: Identification of genes for lignin peroxidases and manganese peroxidases in ectomycorrhizal fungi. New Phytol 2001, 152:151-158.

39. Burke RM, Cairney JW: Laccases and other polyphenol oxidases in ectoand ericoid mycorrhizal fungi. Mycorrhiza 2002, 12:105-116.

40. Salaheddin C, Spadiut O, Ludwig R, Tan TC, Divne C, Haltrich D, Peterbauer $C$ : Probing active-site residues of pyranose 2-oxidase from
Trametes multicolor by semi-rational protein design. Biotechnol J 2009, 4:535-543.

41. Baminger U, Subramaniam SS, Renganathan V, Haltrich D: Purification and characterization of cellobiose dehydrogenase from the plant pathogen Sclerotium (Athelia) rolfsii. Appl Environ Microbiol 2001, 67:1766-1774.

\section{doi:10.1186/1475-2859-9-57}

Cite this article as: Salaheddin et al:: Characterisation of recombinant pyranose oxidase from the cultivated mycorrhizal basidiomycete Lyophyllum shimeji (hon-shimeji). Microbial Cell Factories 2010 9:57.

\section{Submit your next manuscript to BioMed Central and take full advantage of:}

- Convenient online submission

- Thorough peer review

- No space constraints or color figure charges

- Immediate publication on acceptance

- Inclusion in PubMed, CAS, Scopus and Google Scholar

- Research which is freely available for redistribution
C Biomed Central 